\title{
Autonomous marine robotic technology reveals an expansive benthic bacterial community relevant to regional nitrogen biogeochemistry
}

David L. Valentine, G. Burch Fisher, Oscar Pizarro, Carl Kaiser, Dana Yoerger, John A. Breier, and Jonathan Tarn

Supplemental Information: 8 pages (including Title Page); 7 Figures; 1 Table. 

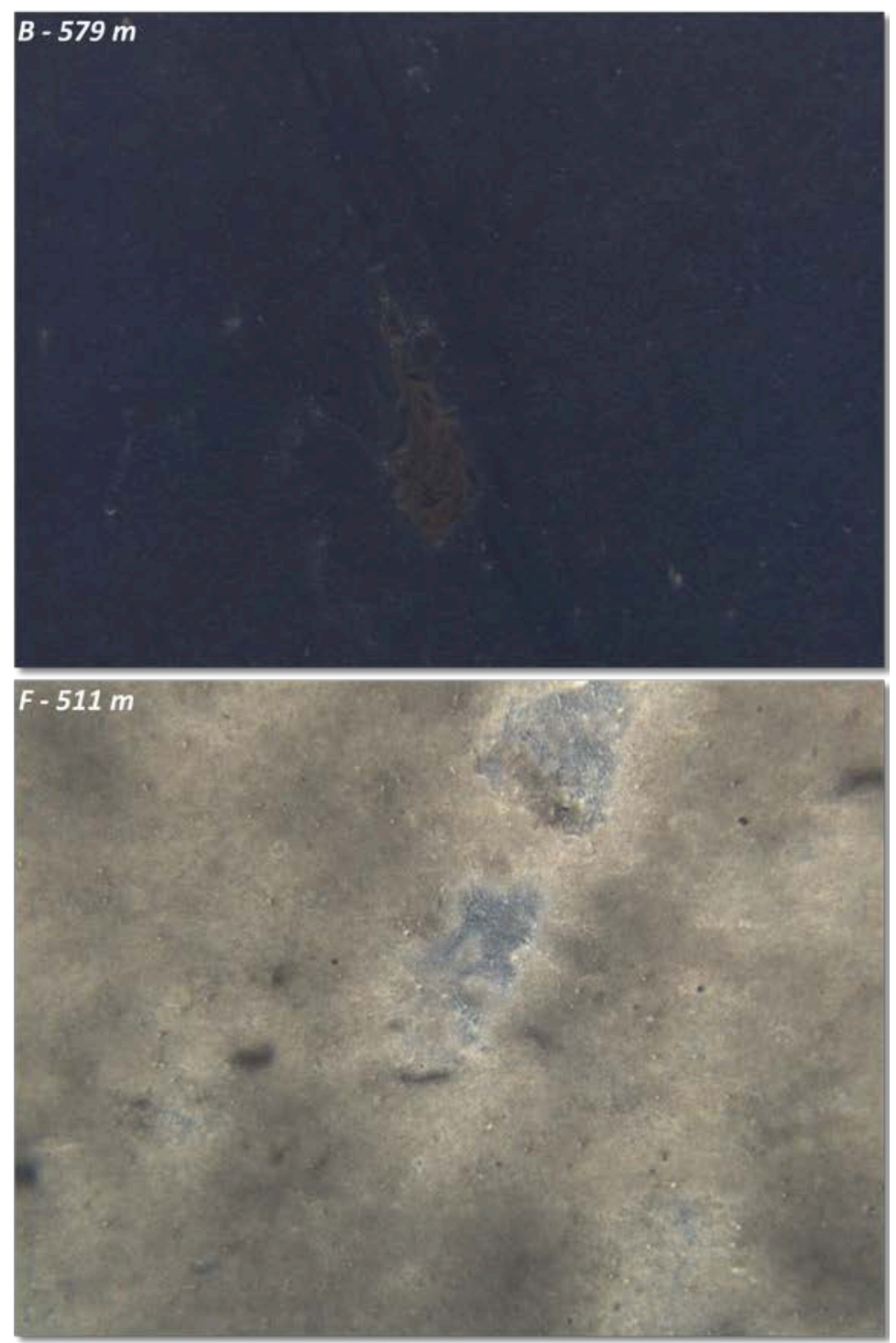

I- $411 \mathrm{~m}$

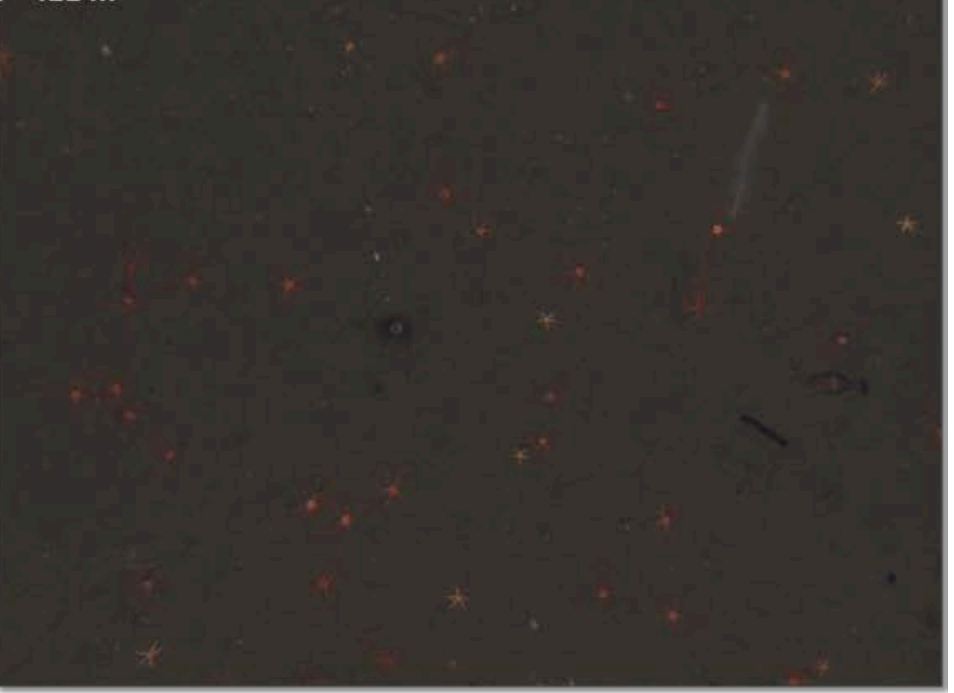

Figure S1 - Full resolution images corresponding to main text, Figure 1B, F and I. 

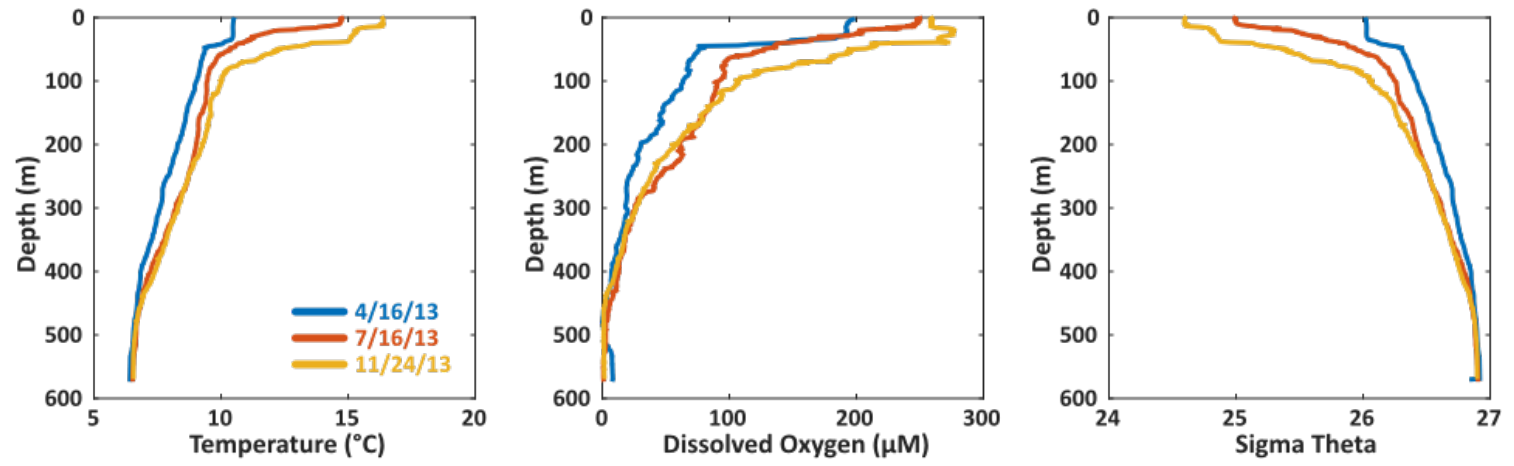

Figure S2 - Temperature, dissolved oxygen, and density anomaly profiles collected in 2013 in the Santa Barbara Basin by the California Cooperative Ocean Fisheries Investigations (CalCOFI). 

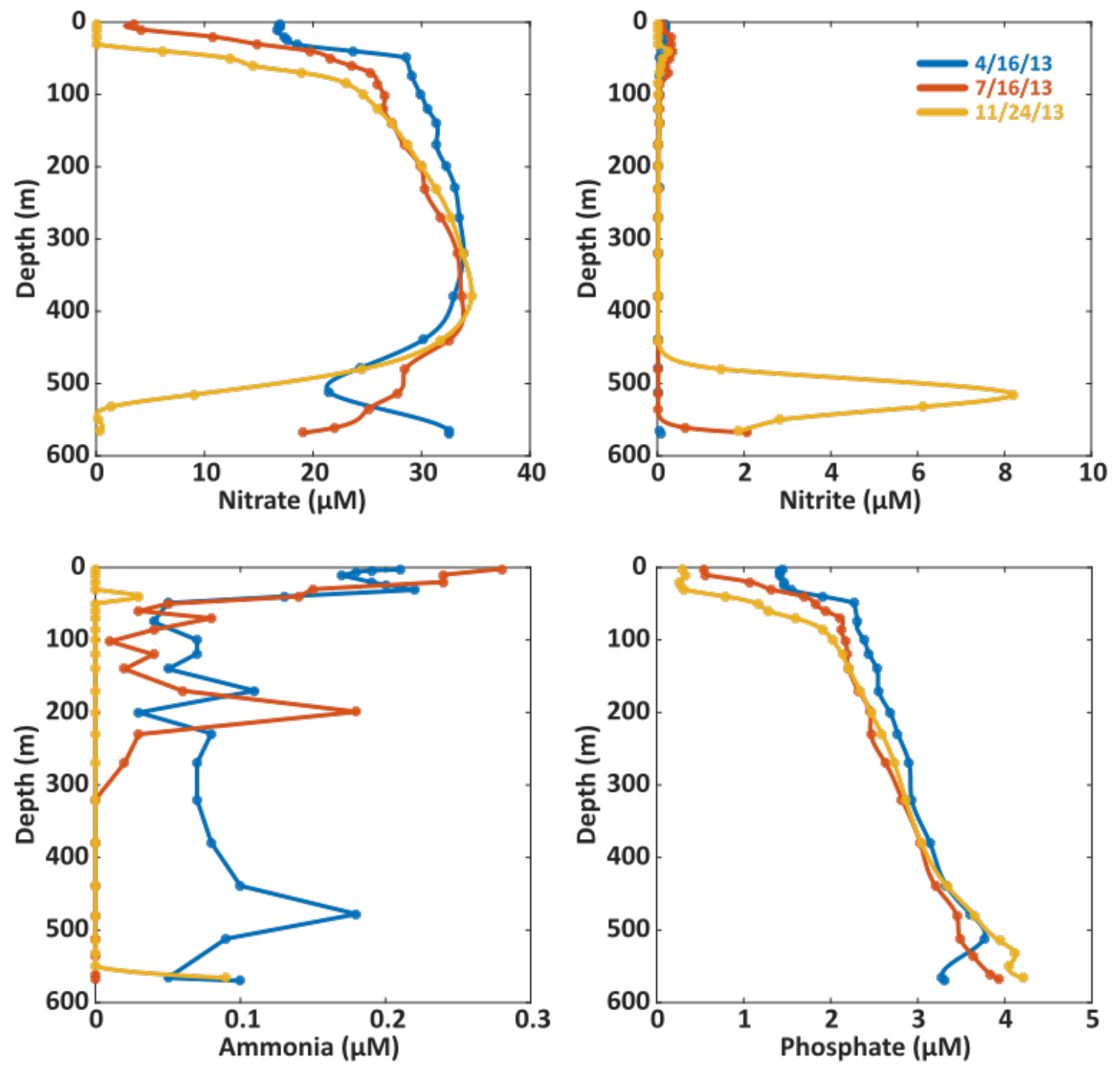

Figure S3 - Interpolated nitrate, nitrite, ammonia, and phosphate profiles collected in 2013 in the Santa Barbara Basin by CalCOFI. Datasets were interpolated using cubic spline fits in all cases except for ammonia, where a simple linear interpolation was used. 

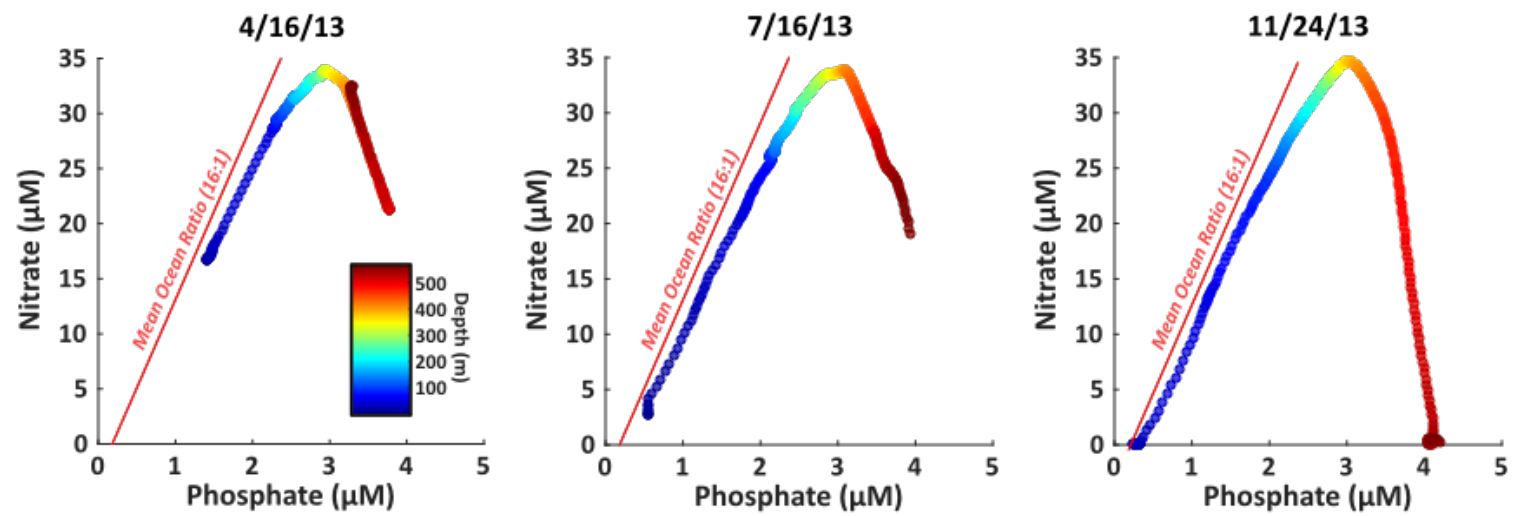

Figure S4 - Plots of nitrate versus phosphate for each CalCOFI sampling date showing consistent deviation from the established Redfield ratio (16:1) at 350 m depth in the basin (depth color gradient is the same for all plots). The slight offset from the mean ocean ratio was used to calculate the preformed component of the phosphate term in equation 1 in the manuscript.
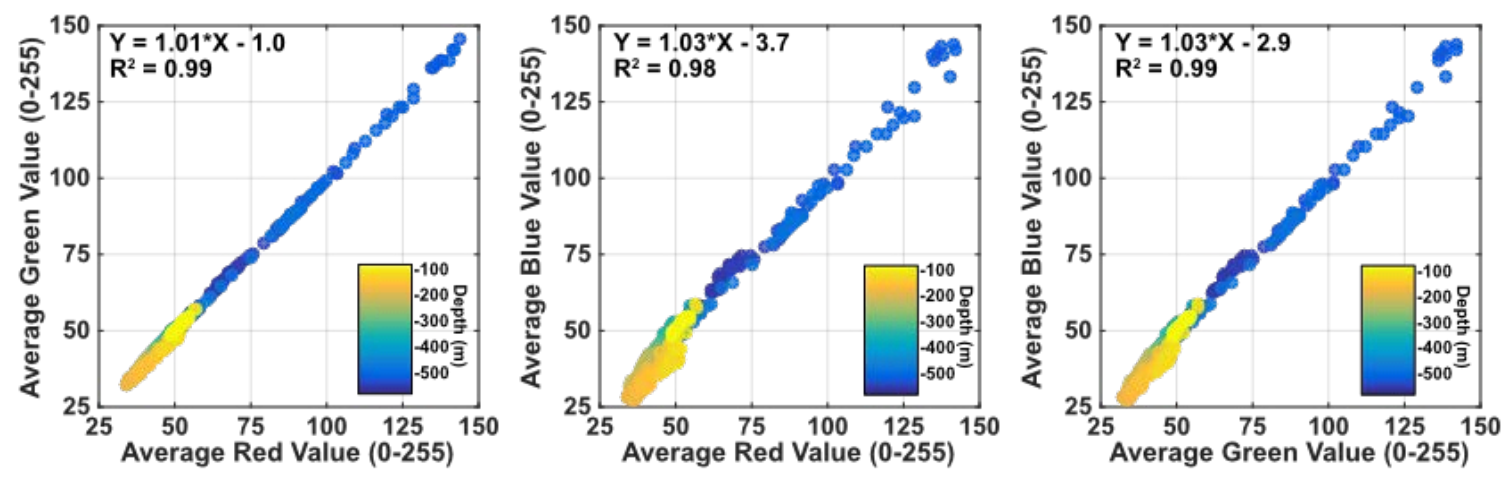

Figure S5 - Average 1-meter depth binned red, green, and blue (RGB) seafloor color values compared to one another. Images were gain corrected to adjust for the variable altitude of the AUV above the seafloor and show near 1:1 relationships with the majority of variance in the shallowest 250 meters where mats are absent. The depth color gradient is the same for all plots. 


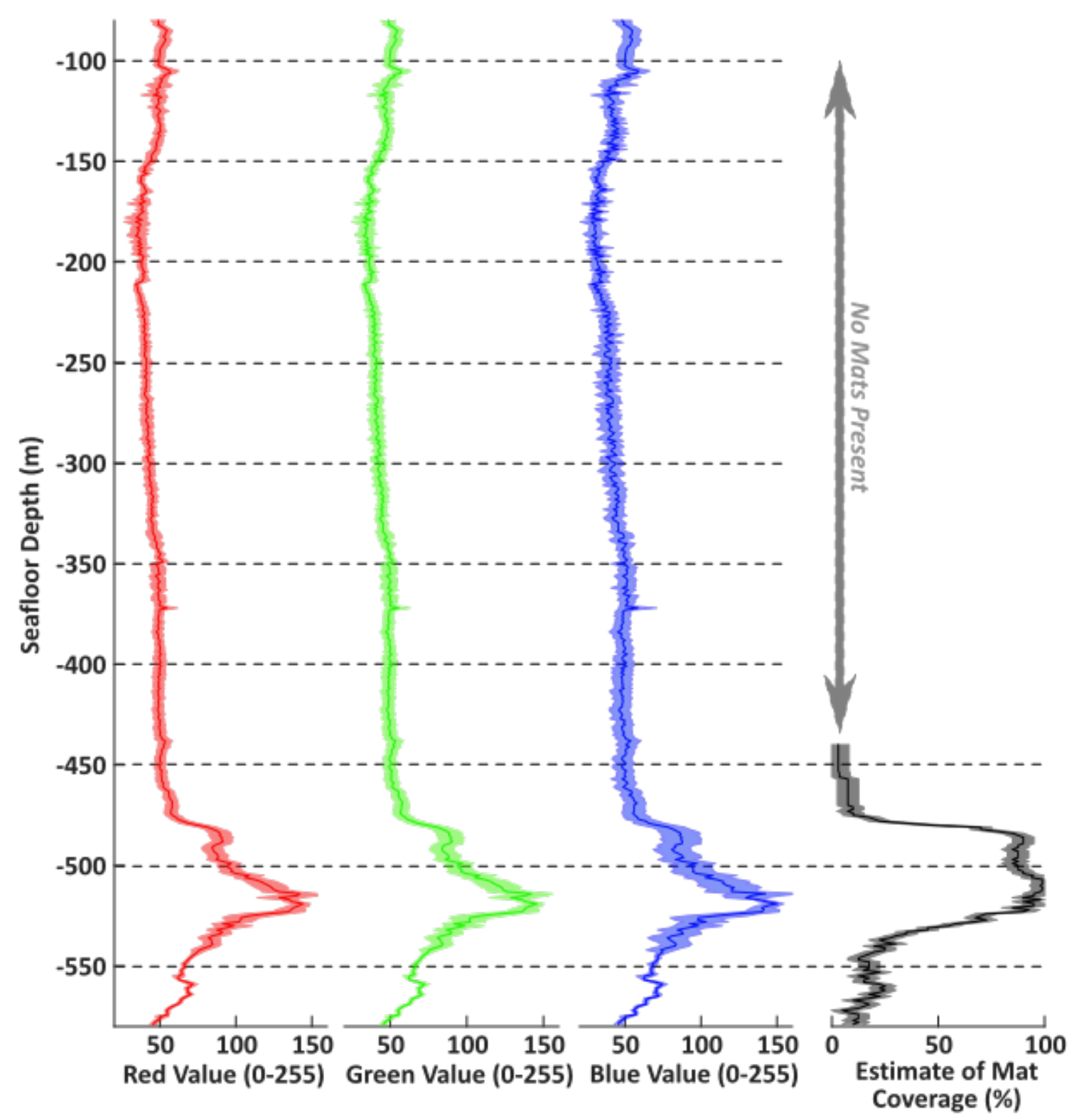

Figure S6 - Average 1-meter depth binned red, green, and blue (RGB) seafloor color profiles and estimate of percent microbial mat coverage. Estimated mat coverage was calculated manually using 159 randomly selected images spanning depths of 80 to 579 meters with one image every meter from 440 to 579 meters depth. Images were blindly assessed by two observers with the estimate of percent coverage determined from the average of the two observations. We assume an absolute error of $\pm 5 \%$ mat coverage on each estimate. 


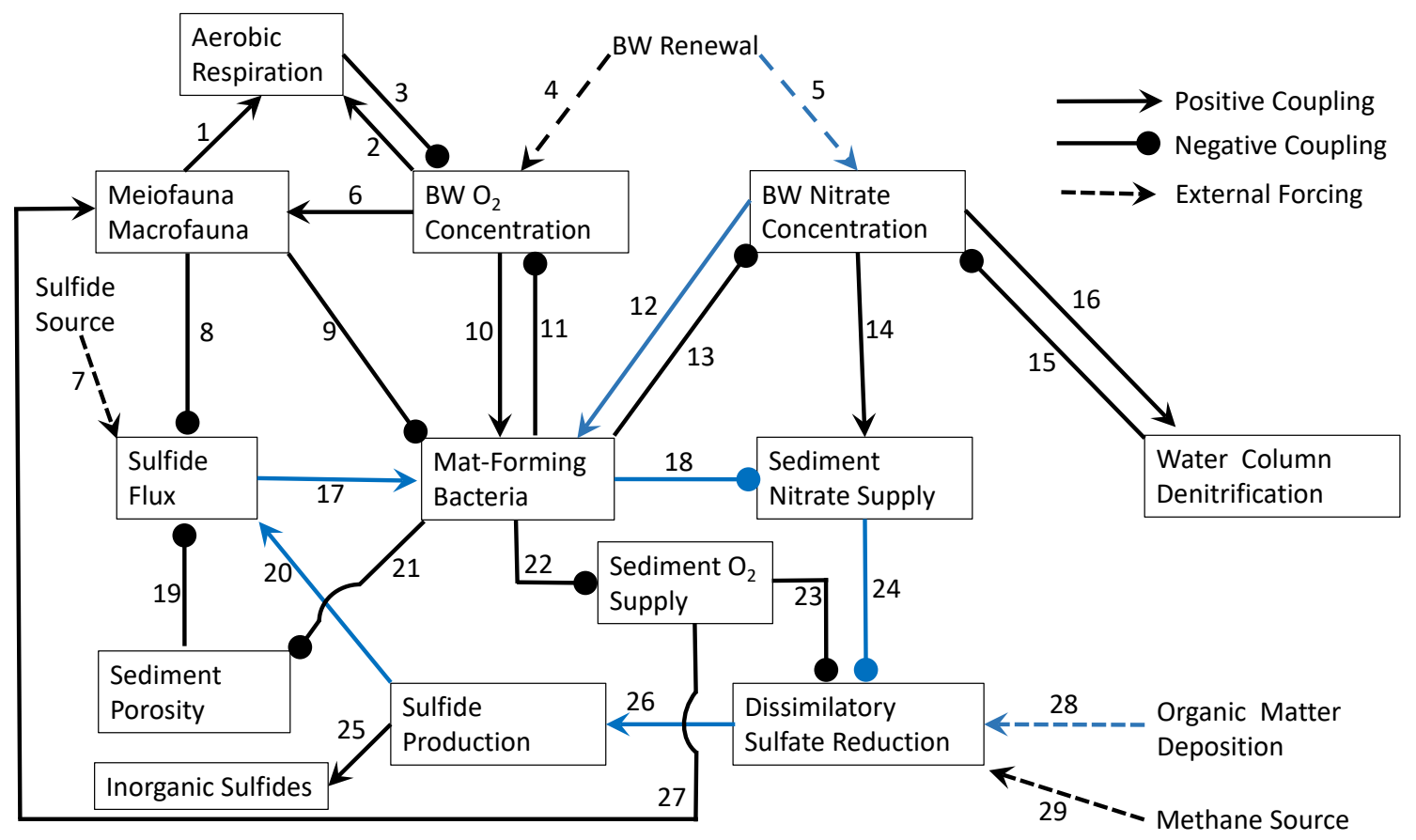

Figure S7 - Environmental fitness landscape for sulfide-oxidizing, mat-forming bacteria, highlighting (in blue) a potential net positive feedback for the community reported in this work. Definitions for numbered processes: 1) Macrofauna and meiofouna conduct aerobic respiration; 2\&3) Bottom water oxygen serves as substrate for respiration and respiration consumes oxygen; 4\&5) Bottom water renewal through flushing can supply a pulse of oxygen and nitrate; 6) Oxygen concentration in the bottom water modulates colonization by macrofauna and meiofouna; 7) Sulfide supplied through external sources, e.g., fluid migration or geochemical sources, increases sulfide flux; 8) Macrofauna and meiofouna disrupt sulfide flux to the sediment surface through burrowing; 9) Select macrofauna and meiofouna graze on microbial mats; 10 \& 11) Bottom water oxygen availability modulates growth of mat-forming bacteria, which in-turn respire oxygen; 12 \& 13) Bottom water nitrate availability modulates growth of mat-forming bacteria, which in-turn accumulate nitrate; 14) Nitrate diffuses through sediment pore space; 15 \& 16) Nitrate in the bottom water modulates denitrification which in turn consumes nitrate; 17) sulfide is used as primary energy source by mat-forming bacteria; 18) Mat forming bacteria modulate nitrate supply to the sediment through uptake and hyperaccumulation; 19) Sediment porosity modulates the diffusive flux of dissolved sulfide; 20) Sulfide production in sediment modulates the rate of flux to the sea floor; 21) The motility of mat-forming bacteria retards consolidation of sediment; 22) Mat-forming bacteria modulate oxygen supply to the sediment through respiration; 23 \& 24) Both sediment oxygen and nitrate supply modulate dissimilatory sulfate reduction; 25) Sulfide production leads to precipitation of inorganic sulfide minerals; 26) Dissimilatory sulfate reduction leads to production of sulfide; 27) Sediment oxygen supply sustains meiofauna and some macrofauna; 28) Organic matter deposition to marine sediments modulates dissimilatory sulfate reduction; 29) Methane or other hydrocarbons supplied through external sources, e.g., fluid migration or geochemical sources, can be metabolized through dissimilatory sulfate reduction. 
Table S1. Gibbs Free Energy of metabolic partitioning ${ }^{a}$

\begin{tabular}{|c|c|c|c|c|c|}
\hline $\mathbf{R x n}^{\mathbf{b}}$ & Reactants & Products & $\Delta \mathrm{G}^{\mathrm{c}}$ & $\%$ of $\Delta G^{\prime}$ & Type $^{\text {d }}$ \\
\hline $1 a$ & $\mathrm{CH}_{3} \mathrm{COO}^{-}+\mathrm{H}_{2} \mathrm{O}$ & $\mathrm{CH}_{4}+\mathrm{HCO}_{3}^{-}$ & -29 & $5.8 \%$ & MET \\
\hline $1 b$ & $\mathrm{CH}_{4}+\mathrm{SO}_{4}^{2-}$ & $\mathrm{HS}^{-}+\mathrm{HCO}_{3}^{-}+\mathrm{H}_{2} \mathrm{O}$ & -39 & $7.7 \%$ & AOM \\
\hline $1 c$ & $\mathrm{HS}^{-}+\mathrm{NO}_{3}^{-}+\mathrm{H}_{2} \mathrm{O}+\mathrm{H}^{+}$ & $\mathrm{SO}_{4}^{2-}+\mathrm{NH}_{4}^{+}$ & -437 & $86.5 \%$ & DNR \\
\hline $2 a$ & $\mathrm{CH}_{3} \mathrm{COO}^{-}+\mathrm{SO}_{4}^{2-}$ & $\mathrm{HS}^{-}+2 \mathrm{HCO}_{3}^{-}$ & -68 & $13.5 \%$ & DSR \\
\hline $2 b$ & $\mathrm{HS}^{-}+\mathrm{NO}_{3}^{-}+\mathrm{H}_{2} \mathrm{O}+\mathrm{H}^{+}$ & $\mathrm{SO}_{4}^{2-}+\mathrm{NH}_{4}^{+}$ & -437 & $86.5 \%$ & DNR \\
\hline Net $1 / 2$ & $\mathrm{CH}_{3} \mathrm{COO}^{-}+\mathrm{H}^{+}+\mathrm{H}_{2} \mathrm{O}+\mathrm{NO}_{3}^{-}$ & $\mathrm{NH}_{4}^{+}+2 \mathrm{HCO}_{3}^{-}$ & -505 & $100 \%$ & COM \\
\hline $3 a$ & $\mathrm{C}_{6} \mathrm{H}_{12} \mathrm{O}_{6}+4 \mathrm{H}_{2} \mathrm{O}$ & $2 \mathrm{CH}_{3} \mathrm{COO}^{-}+2 \mathrm{HCO}_{3}^{-}+4 \mathrm{H}^{+}+4 \mathrm{H}_{2}$ & -369 & $20 \%$ & FER \\
\hline $3 b$ & $2 \mathrm{CH}_{3} \mathrm{COO}^{-}+2 \mathrm{SO}_{4}^{2-}$ & $2 \mathrm{HS}^{-}+4 \mathrm{HCO}_{3}^{-}$ & -136 & $7 \%$ & DSR \\
\hline $3 c$ & $4 \mathrm{H}_{2}+\mathrm{SO}_{4}^{2-}+\mathrm{H}^{+}$ & $\mathrm{HS}^{-}+4 \mathrm{H}_{2} \mathrm{O}$ & -64 & $3 \%$ & DSR \\
\hline $3 d$ & $3 \mathrm{HS}^{-}+3 \mathrm{NO}_{3}^{-}+3 \mathrm{H}_{2} \mathrm{O}+3 \mathrm{H}^{+}$ & $3 \mathrm{SO}_{4}^{2-}+3 \mathrm{NH}_{4}^{+}$ & -1311 & $70 \%$ & DNR \\
\hline $4 a$ & $\mathrm{C}_{6} \mathrm{H}_{12} \mathrm{O}_{6}+3 \mathrm{SO}_{4}^{2-}$ & $3 \mathrm{HS}^{-}+6 \mathrm{HCO}_{3}^{-}+3 \mathrm{H}^{+}$ & -569 & $30 \%$ & DSR \\
\hline $4 b$ & $3 \mathrm{HS}^{-}+3 \mathrm{NO}_{3}^{-}+3 \mathrm{H}_{2} \mathrm{O}+3 \mathrm{H}^{+}$ & $3 \mathrm{SO}_{4}^{2-}+3 \mathrm{NH}_{4}^{+}$ & -1311 & $70 \%$ & DNR \\
\hline Net $3 / 4$ & $\mathrm{C}_{6} \mathrm{H}_{12} \mathrm{O}_{6}+3 \mathrm{H}_{2} \mathrm{O}+3 \mathrm{NO}_{3}^{-}$ & $3 \mathrm{NH}_{4}^{+}+6 \mathrm{HCO}_{3}^{-}$ & -1880 & $100 \%$ & COM \\
\hline
\end{tabular}

${ }^{a}$ Exemplary metabolism are provided for a low energy substrate (acetate) and a high energy substrate (glucose). ${ }^{\mathrm{b}}$ Net refers to the net chemical reaction with reaction series $1=2$, and $3=4$. c The following aqueous concentrations at $280 \mathrm{~K}$ were assumed for the calculation of $\Delta \mathrm{G}^{\prime}$ in molar units unless otherwise specified: $\mathrm{CH}_{3} \mathrm{COO}^{-}=10^{-5} ; \mathrm{H}^{+}=10^{-7} ; \mathrm{CH}_{4}=10^{-2}$ (bar); $\mathrm{HCO}_{3}{ }^{-}=$ $2 \times 10^{-3} ; \mathrm{SO}_{4}{ }^{2-}=3 \times 10^{-2} ; \mathrm{HS}^{-}=10^{-5} ; \mathrm{NO}_{3}{ }^{-}=3 \times 10^{-5} ; \mathrm{NH}_{4}{ }^{+}=10^{-6} . ; \mathrm{C}_{6} \mathrm{H}_{12} \mathrm{O}_{6}=10^{-5} ; \mathrm{H}_{2}=10^{-5}$ (bar); $\Delta \mathrm{G}^{\prime}$ in units of $\mathrm{kJ} \mathrm{mol}^{-1}$. ${ }^{\mathrm{d}}$ Metabolic type defined as: methanogenesis (MET); anaerobic oxidation of methane (AOM); dissimilatory nitrate reduction (DNR); dissimilatory sulfate reduction (DSR); net community metabolism (COM); fermentation (FER). 